\title{
THE IMPACT OF INDOOR CYCLING TRAINING ON EXERCISE CAPACITY AND BLOOD LIPID PROFILE OF MEN WITH ISCHAEMIC HEART DISEASE OR AFTER MYOCARDIAL INFARCTION
}

\author{
Dagmara Gloc, Zbigniew Nowak
}

\begin{abstract}
Aim. In the present study attempts to determine the impact of 1-month Indoor Cycling training on exercise capacity and blood lipid profile were made.

Material and methods. The study group consisted of 50 men under the model A of the 2nd phase of cardiac rehabilitation (20 men of the Indoor Cycling group, IC, 20 men rehabilitated accordingly to the recommendations of the Polish Cardiac Society - a standard group, ST and 10 people who did not participate in any cardiac rehabilitation program - a control group, $\mathrm{C}$ ). The average age of all subjects was $56,60 \pm 8,25$ years, the average left ventricular ejection fraction was $56 \% \pm 4,00$.

Results. In the IC group there was a significant increase in the test duration ( $8,47 \mathrm{vs}$ $10,23 \mathrm{~min} ; \mathrm{p}<0,001)$, a significant increase in the MET value $(10,86$ vs 12,35 ; $\mathrm{p}=0,06)$ and $\mathrm{VO}_{2} \max (38,43$ vs $48,25 \mathrm{ml} / \mathrm{kg} / \mathrm{min} ; \mathrm{p}<0,001)$. Parallel changes were observed in the ST group, where the following parameters improved: the test duration $(8,51$ vs 9,$96 ; p<0,001)$, MET value $(10,57$ vs 12,$18 ; p=0,002)$ and $\mathrm{VO}_{2} \max$ $(38,42$ vs 46,$24 ; p<0,001)$. No significant changes in rest and maximum heart rate as well as systolic and diastolic blood pressure parameters were found. In C group no significant changes in treadmill exercise test parameters were observed. Alike in the IC, ST as well as in the $\mathrm{C}$ group, positive modification of blood lipid profile was observed. The significant increase in the average value of $\mathrm{HDL}$ cholesterol in the control group $(41,00$ vs $49,52 \mathrm{mg} / \mathrm{dl} ; \mathrm{p}<0,05)$ was only found.

Conclusion. Indoor Cycling training in the second phase of cardiac rehabilitation is a safe form of therapy and therefore may be an interesting alternative
\end{abstract}

method to the classic bicycle ergometer exercise in the stage of an early cardiac rehabilitation.

Russ J Cardiol 2016, 4 (132), Engl.: 153-159

http://dx.doi.org/10.15829/1560-4071-2016-4-eng-153-159

Key words: comprehensive cardiac rehabilitation, coronary heart disease, Indoor Cycling, Percutaneous Coronary Intervention, physical activity, myocardial infarction.

Faculty of Physiotherapy, Academy of Physical Education, Katowice, Poland.

Corresponding author. Dagmara Gloc, Faculty of Physiotherapy, Academy of Physical Education, Mikołowska str. 72a, 40-065 Katowice, Poland. e-mail: glocdagmara@gmail.com

$\mathrm{CABG}$ - coronary artery bypass grafting, $\mathrm{CHS}$ - cardiac health status, $\mathrm{PCl}$ - percutaneous coronary intervention.

Received January 12, 2016.

Revision received January 14, 2016.

Accepted January 21, 2016.

\section{ВЛИЯНИЕ ВЕЛОСПОРТИВНЫХ ТРЕНИРОВОК НА ТОЛЕРАНТНОСТЬ К ФИЗИЧЕСКОЙ НАГРУЗКЕ И ЛИПИДНЫЙ СПЕКТР КРОВИ У МУЖЧИН С ИШЕМИЧЕСКОЙ БОЛЕЗНЬЮ СЕРДЦА ИЛИ ПОСЛЕ ИНФАРКТА МИОКАРДА}

\author{
Dagmara Gloc, Zbigniew Nowak
}

\begin{abstract}
Цель. В настоящем исследовании предпринята попытка определения влияния 1-го месяца велоспортивных тренировок на толерантность к физической нагрузке и липидный профиль крови.

Материал и методы. Исследовательская группа состояла из 50 человек проходила испытания по модели А 2-го этапа кардиологической реабилитации (20 человек группа велоспортивных тренировок (IC), 20 мужчин проходили реабилитацию соответственно рекомендациям польского кардиологического общества - стандартная группа (ST), группа 10 человек, которые не принимали участия ни в сердечной программе реабилитации - контрольная группа, С).

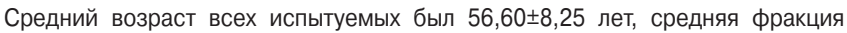
выброса левого желудочка составляла $56 \% \pm 4,00$.

Результаты. В IC группе наблюдалось значительное увеличение продолжительности испытания (8,47 против 10,23 мин; $p<0,001)$, значительное увеличение значения MET $(10,86$ против 12,35; $\mathrm{p}=0,06)$ и $\mathrm{VO}_{2} \max (38,43$ против 48,25 мл/кг/мин; p<0,001). Параллельно наблюдались изменения в ST группе, где показатели улучшились: длительность теста $(8,51$ против $9,96 ; p<0,001)$, значения МЕT (10,57 против 12,18; $=0,002)$ и VO $\max (38,42$ против 46,$24 ; p<0,001)$. Не было обнаружено значительных изменений показателей в покое, максимальной частоты сердечных сокращений,
\end{abstract}

The most commonly used, yet traditional training forms according to the Cardiac Rehabilitation Standards of Polish Cardiac Society, are aerobic (endurance) training in the form of walking on the treadmill or in the field, bicycle ergometer training, swimming, training on the bicycle, and anaerobic training (anaerobic resistance training) $[1,2]$. Physical training, which is introduced in а также систолического и диастолического артериального давления. В группе C никаких существенных изменений в на тредмиле не наблюдалось. Как в IC, так и в ST, а также в группе C, положительных изменений липидного профиля крови не наблюдалось. Было отмечено значительное увеличение среднего значения холестерина ЛПВП в группе контроля $(41,00$ против 49,52 мг/дл; р<0,05).

Заключение. Велоспортивные тренировки на втором этапе кардиологической реабилитации являются безопасной формой терапии и, следовательно, могут быть интересной альтернативой методу классической велоэргометрвелотренажер в стадии ранней кардиологической реабилитации.

Российский кардиологический журнал 2016, 4 (132), Англ.: 153-159 http://dx.doi.org/10.15829/1560-4071-2016-4-eng-153-159

Ключевые слова: комплексная реабилитация сердца, ишемическая болезнь сердца, езда на велосипеде, чрескожное коронарное вмешательство, физическая активность, инфаркт миокарда.

Faculty of Physiotherapy, Academy of Physical Education, Katowice, Польша.

the second stage of cardiac rehabilitation, is well understood and described, but rare publications on the use of modern, innovative forms of exercises for patients with cardiovascular diseases can be found. Younger age of the cardiac patients somehow necessitates the use of modern forms of physical training, which become alternative, interesting and engaging means to provide effective reha- 
Table 1

Table 4

Characteristics of the Indoor Cycling, standard and control group

\begin{tabular}{|l|l|l|l|}
\hline Variable & $\begin{array}{l}\text { Indoor Cycling } \\
\text { group } \\
(\mathrm{n}=20)\end{array}$ & $\begin{array}{l}\text { Standard } \\
\text { group } \\
(\mathrm{n}=20)\end{array}$ & $\begin{array}{l}\text { Control } \\
\text { group } \\
(\mathrm{n}=10)\end{array}$ \\
\hline Age [years] & $\begin{array}{l}57,50 \pm 9,51 \\
(39-72)\end{array}$ & $\begin{array}{l}56,40 \pm 9,85 \\
(40-70)\end{array}$ & $\begin{array}{l}55,40 \pm 8,25 \\
(46-67)\end{array}$ \\
\hline Body height $[\mathrm{cm}]$ & $\begin{array}{l}178 \pm 5,46 \\
(168-191)\end{array}$ & $\begin{array}{l}176,40 \pm 5,95 \\
(164-190)\end{array}$ & $\begin{array}{l}174,90 \pm 8,03 \\
(164-190)\end{array}$ \\
\hline Body weight $[\mathrm{kg}]$ & $\begin{array}{l}84,15 \pm 9,35 \\
(70-104)\end{array}$ & $\begin{array}{l}87,02 \pm 14,08 \\
(66,90-117,90)\end{array}$ & $\begin{array}{l}81,15 \pm 16,27 \\
(63,40-117,30)\end{array}$ \\
\hline BMI $\left[\mathrm{kg} / \mathrm{m}^{2}\right]$ & $26,58 \pm 2,61$ & $27,84 \pm 3,20$ & $26,29 \pm 3,32$ \\
\hline LVEF $[\%]$ & $(21,20-32,60)$ & $(22,80-34,60)$ & $(22,60-32,50)$ \\
\hline & $56,05 \pm 3,91$ & $56,10 \pm 4,19$ & $55,70 \pm 4,00$ \\
\hline
\end{tabular}

Abbreviations: BMI - body mass index, LVEF - left ventricular ejection fraction, $\mathrm{n}-$ the number of patients.

The type of diseases in the Indoor Cycling, standard and control group

\begin{tabular}{|l|l|l|l|}
\hline Type of disease & $\begin{array}{l}\text { Indoor Cycling } \\
\text { group } \\
\mathrm{n}(\%)\end{array}$ & $\begin{array}{l}\text { Standard } \\
\text { group } \\
\mathrm{n}(\%)\end{array}$ & $\begin{array}{l}\text { Control } \\
\text { group } \\
\mathrm{n}(\%)\end{array}$ \\
\hline Ischemic heart disease & $20(100 \%)$ & $20(100 \%)$ & $10100 \%)$ \\
\hline Type 2 diabetes & $4(20 \%)$ & $5(25 \%)$ & $2(20 \%)$ \\
\hline Hyperlipidemia & $6(30 \%)$ & $3(15 \%)$ & $0(0 \%)$ \\
\hline Hypertension & $16(80 \%)$ & $17(85 \%)$ & $8(80 \%)$ \\
\hline Miocardial infarction & $16(80 \%$ & $16(80 \%)$ & $5(50 \%)$ \\
\hline Total & $20(100 \%)$ & $20(100 \%)$ & $10(100 \%)$ \\
\hline
\end{tabular}

Abbreviation: $\mathrm{n}-$ the number of patients.

Table 3

The method of treatment in the Indoor Cycling, standard and control group

\begin{tabular}{|l|l|l|l|}
\hline Method of treatment & $\begin{array}{l}\text { Indoor Cycling } \\
\text { group } \\
\mathrm{n}(\%)\end{array}$ & $\begin{array}{l}\text { Standard } \\
\text { group } \\
\mathrm{n}(\%)\end{array}$ & $\begin{array}{l}\text { Control } \\
\text { group } \\
\mathrm{n}(\%)\end{array}$ \\
\hline $\mathrm{PCl}+$ STENT & $16(80 \%)$ & $17(85 \%)$ & $8(80 \%)$ \\
\hline $\mathrm{PCl}$ & $4(20 \%)$ & $3(15 \%)$ & $2(20 \%)$ \\
\hline Total & $20(100 \%)$ & $20(100 \%)$ & $10(100 \%)$ \\
\hline
\end{tabular}

Abbreviations: $\mathrm{n}-$ the number of patients, $\mathrm{PCl}-$ percutaneous coronary intervention/

bilitation [3]. One such form is endurance Indoor Cycling training. Properly conducted training consists of a warm-up, an appropriate training and an end portion cool down and stretching, which concerns proper muscle groups and tendons. Indoor Cycling training can be carried out in three basic positions of the hands (open, close and forward), in sitting or standing techniques [4]. There are no reports on the possibilities of the use of Indoor Cycling as an alternative form to the traditional endurance cycle ergometer training of patients with cardiovascular diseases.
The number of stents implanted in the Indoor Cycling, standard and control group

\begin{tabular}{|l|l|l|l|}
\hline Number of stents & $\begin{array}{l}\text { Indoor Cycling } \\
\text { group } \\
\mathrm{n}(\%)\end{array}$ & $\begin{array}{l}\text { Standard } \\
\text { group } \\
\mathrm{n}(\%)\end{array}$ & $\begin{array}{l}\text { Control } \\
\text { group } \\
\mathrm{n}(\%)\end{array}$ \\
\hline $\mathbf{0}$ & $4(20 \%)$ & $3(15 \%)$ & $2(20 \%)$ \\
\hline $\mathbf{1}$ & $12(60 \%)$ & $10(50 \%)$ & $5(50 \%)$ \\
\hline $\mathbf{2}$ & $1(5 \%)$ & $5(25 \%)$ & $3(30 \%)$ \\
\hline $\mathbf{3}$ & $1(5 \%)$ & $1(5 \%)$ & $0(0 \%)$ \\
\hline $\mathbf{4}$ and more & $2(10 \%)$ & $1(5 \%)$ & $0(\%)$ \\
\hline Total & $20(100 \%)$ & $20(100 \%)$ & $10(100 \%)$ \\
\hline
\end{tabular}

Abbreviation: $\mathrm{n}-$ the number of patients.

Table 5

The protocol of the Indoor Cycling training unit

\begin{tabular}{|c|c|c|c|c|}
\hline $\begin{array}{l}\text { Part of the } \\
\text { training session }\end{array}$ & $\begin{array}{l}\text { Time } \\
(\mathrm{min})\end{array}$ & $\begin{array}{l}\text { Borg } \\
\text { scale }\end{array}$ & RPM & Position / technique \\
\hline Warm-up & $1-5$ & $9-10$ & $100-110$ & 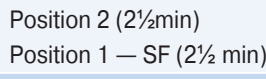 \\
\hline $\begin{array}{l}\text { Appropriate } \\
\text { training }\end{array}$ & $\begin{array}{l}17,5-22,5 \\
22,5-27,5\end{array}$ & $\begin{array}{l}12-13 \\
12-14\end{array}$ & $\begin{array}{l}110 \\
110 \\
80 \\
80 \\
100-110 \\
100 \\
80-100 \\
100 \\
60-80 \\
100 \\
80 \\
80 \\
80 \\
100-110\end{array}$ & 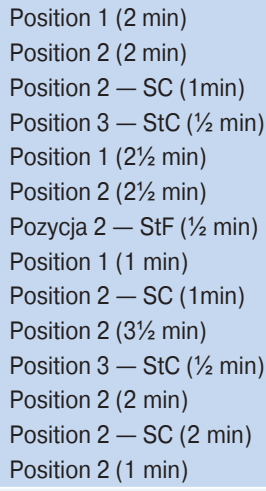 \\
\hline Cool down & $27,5-30$ & $9-10$ & 100 & Position 1 - SF \\
\hline Stretching & $30-35$ & 9 & - & - \\
\hline
\end{tabular}

Abbreviations: min - minute, position 1 - close, position 2 - open, position 3- forward, RPM - Revolutions Per Minute, SC - Seated Climb, SF - Seated Flat, $\mathrm{StC}-$ Standing Climb, StF - Standing Fl at.

In the present study attempts to determine the impact of 22 Indoor Cycling training units (1-month) on exercise capacity and blood lipid profile were made.

\section{Material and methods}

The study group consisted of 50 men under the model A of the second phase of cardiac rehabilitation (results of exercise treadmill test $\geq 7$ MET or $100 \mathrm{~W}$ ). Groups were comparable in terms of age, body height, body weight and left ventricular ejection fraction. Their characteristics are shown in Table $1.100 \%$ of patients experienced ischemic heart disease, $74 \%$ of them had a myocardial infarction (Table 2). The prevailing type of treatment in the study population was percutaneous coronary intervention (PCI) combined with implantation of 1 stent (Table 3 and 4). 


\section{Methodology of training according to the recommendations of the Section of Cardiac Rehabilitation and Physiology Effort Polish Cardiac Society}

\begin{tabular}{|c|c|c|}
\hline The type of training & Methodology & Workload \\
\hline Endurance training & $\begin{array}{l}\text { Training on a bicycle ergometer, } \\
5 \text { times a week } \\
30 \text { minutes }\end{array}$ & \multirow{2}{*}{$\begin{array}{l}\text { The workload applied on the basis of } \\
\text { calculation of heart rate training, starting from } \\
60 \% \text { of heart rate reserve increased by } 10 \% \\
\text { after } 5 \text { units of training, to } 80 \% \text { of heart rate } \\
\text { reserve, } 14 \text { degrees of subjective scale effort } \\
\text { assessment by the Borg scale }\end{array}$} \\
\hline Resistance training & $\begin{array}{l}\text { Exercises in the form of training station, } \\
5 \text { times a week } \\
30 \text { minutes }\end{array}$ & \\
\hline
\end{tabular}

Between November 2014 and January 2015, reducing the number of confounding factors such as age, sex, disease entity, method of treatment, the level of exercise capacity, 50 patients enrolled in the study were allocated according to random selection into the three groups: 20 men, members of the Indoor Cycling group, IC, 20 men rehabilitated accordingly to the recommendations of the Section of Cardiac Rehabilitation and Physiology Effort Polish Cardiac Society - a standard group, ST and 10 people who did not participate in any cardiac rehabilitation program - a control group, C). Patients (except from the $\mathrm{C}$ group) underwent 22 training units performed 5 times a week. In the ST group the training included: endurance exercise on a bicycle ergometer, resistance training and calisthenics (general exercises). Whereas men in the IC group, instead of the traditional interval training on the ergometer, participated in the Indoor Cycling lessons arranged by the same instructor (Table 5). That group also participated in the other two types of trainings (resistance and calisthenics) according to the standards (Table 6). Heart rate frequency was constantly individually monitored during each lesson by the heart rate monitor (Polar FT1), as well as by the instructor.

Inclusion criteria were: formal consent to participate in the study, stable coronary heart disease or uncomplicated course of myocardial infarction, time of last cardiovascular event not less than 2 months and not more than 6 months, an exercise test results $\geq 7$ MET / 100W, left ventricular ejection fraction $\geq 50 \%$. Exclusion criteria were: lack of formal consent to participate in the study, recent myocardial infarction, $<2$ months of a cardiovascular event, left ventricular ejection fraction $<50 \%$, the surgical treatment of coronary artery disease (CABG), unregulated hypertension, unstable ischemic heart disease, arrhythmias, diagnosed cancer, diseases of the central or peripheral nervous system, varicose veins of the lower limbs, degenerative disease of the peripheral joints and spine, past unhealed injuries of the lower limbs, advanced peripheral vascular disease, age $\geq 75$ and incomplete medical documentation. At the beginning and after 1-month in all groups submax- imal exercise treadmill test according to the standard Bruce protocol was performed. The exercise test was terminated in case of a limit heart rate, fatigue, high blood pressure over $230 / 120 \mathrm{mmHg}$, ST-segment depression of at least $2 \mathrm{~mm}$, coronary pain and blood pressure drop above $10 \mathrm{mmHg}$ from baseline. Behind a positive exercise test criterion adopted horizontal or diagonal to the bottom depression of ST-segment at least $1 \mathrm{~mm}$ measured $80 \mathrm{~ms}$ after the J point. The following parameters were evaluated: duration of the test exercise [minute], MET value, resting and maximum heart rate [beats/minute], resting and maximum blood pressure $[\mathrm{mmHg}]$, resting and maximum double product $[\mathrm{mmHg} \times \min ]$, maximal oxygen uptake $\mathrm{VO}_{2} \max [\mathrm{ml} / \mathrm{kg} / \mathrm{min}]$ due to the lack of directly measure instruments, the indirect method was appointed by the formula:

$V_{2} \max =13,3-0,03(t)+0,297\left(t^{2}\right)-0,0077\left(t^{2}\right)+4,2(C H S)$ where: $\mathrm{t}$ - time [min]

CHS (cardiac health status) -1 : patients with angina pectoris, myocardial infarction, revascularization, 0 : patients without symptoms of angina, without a completed myocardial and without revascularization procedures performed) [5].

At the beginning and after 1-month total cholesterol, HDL and LDL fractions and triglycerides $[\mathrm{mg} / \mathrm{dl}]$ were also analyzed. The assessment of blood lipid profile was made in the analytical laboratory.

The study was performed according to the Good Clinical Practice guidelines and the Declaration of Helsinki. The study protocol was approved by the local Committee of Ethics of the Academy of Physical Education in Katowice - Poland (The Resolution No. 6/2014 of 15.05.2014). Written informed consent was obtained from all participants prior to their inclusion in the study.

For all numerical parameters the arithmetic mean, minimum, maximum and standard deviation were calculated. For the presentation of qualitative data the prevalence of studied traits were used. In order to verify assumptions of tests the Shapiro-Wilk normality test was performed. For the analysis of relationships between variables 
Table 7

\section{Results of the treadmill exercise test in three groups of patients before (I) and at the end (II) of cardiac rehabilitation}

\begin{tabular}{|c|c|c|c|c|c|c|}
\hline Variable & $\begin{array}{l}\text { Indoor Cycling } \\
\text { group } \\
(n=20)\end{array}$ & $p$ & $\begin{array}{l}\text { Standard } \\
\text { group } \\
(n=20)\end{array}$ & $p$ & $\begin{array}{l}\text { Control } \\
\text { group } \\
(n=10)\end{array}$ & $p$ \\
\hline $\begin{array}{l}\text { Time I } \\
\text { Time II } \\
\Delta \\
{[\mathrm{min}]}\end{array}$ & $\begin{array}{l}8,47 \pm 1,22 \\
10,23 \pm 1,66 \\
1,76^{* * *}\end{array}$ & 0,000 & $\begin{array}{l}8,51 \pm 0,89 \\
9,96 \pm 1,12 \\
1,45^{* *}\end{array}$ & 0,000 & $\begin{array}{l}8,76 \pm 1,11 \\
8,27 \pm 1,40 \\
-0,49\end{array}$ & 0,815 \\
\hline $\begin{array}{l}\text { MET I } \\
\text { MET II } \\
\Delta\end{array}$ & $\begin{array}{l}10,86 \pm 1,20 \\
12,35 \pm 1,43 \\
1,50 \# \#\end{array}$ & 0,006 & $\begin{array}{l}10,57 \pm 0,95 \\
12,18 \pm 1,42 \\
1,62 \# \#\end{array}$ & 0,002 & $\begin{array}{l}11,06 \pm 2,31 \\
10,00 \pm 1,68 \\
-1,06\end{array}$ & 0,433 \\
\hline $\begin{array}{l}\text { HRrest I } \\
\text { HRrest II } \\
\Delta \\
\text { [beats/minute] }\end{array}$ & $\begin{array}{l}65,55 \pm 9,06 \\
69,40 \pm 10,31 \\
3,85\end{array}$ & 0,454 & $\begin{array}{l}72,10 \pm 9,15 \\
69,40 \pm 9,73 \\
-2,70\end{array}$ & 0,790 & $\begin{array}{l}78,60 \pm 7,09 \\
76,40 \pm 4,99 \\
-2,20\end{array}$ & 0,975 \\
\hline $\begin{array}{l}\text { HRmax I } \\
\text { HRmax II } \\
\Delta \\
\text { [beats/minute] }\end{array}$ & $\begin{array}{l}123,50 \pm 14,99 \\
131,15 \pm 13,37 \\
7,65\end{array}$ & 0,169 & $\begin{array}{l}124,75 \pm 14,69 \\
131,65 \pm 14,20 \\
6,90\end{array}$ & 0,264 & $\begin{array}{l}132,20 \pm 15,88 \\
132,80 \pm 8,95 \\
0,60\end{array}$ & 0,999 \\
\hline $\begin{array}{l}\text { RRSrest I } \\
\text { RRSrest II } \\
\Delta \\
{[\mathrm{mmHg}]}\end{array}$ & $\begin{array}{l}127,00 \pm 15,59 \\
126,25 \pm 13,16 \\
-0,75\end{array}$ & 0,999 & $\begin{array}{l}125,00 \pm 13,96 \\
126,50 \pm 9,88 \\
1,50\end{array}$ & 0,996 & $\begin{array}{l}129,00 \pm 12,64 \\
138,50 \pm 16,50 \\
9,50\end{array}$ & 0,298 \\
\hline $\begin{array}{l}\text { RRDrest I } \\
\text { RRDrest II } \\
\Delta \\
{[\mathrm{mmHg}]}\end{array}$ & $\begin{array}{l}81,00 \pm 8,52 \\
80,00 \pm 10,26 \\
-1,00\end{array}$ & 0,994 & $\begin{array}{l}78,75 \pm 6,66 \\
78,00 \pm 5,23 \\
-0,75\end{array}$ & 0,998 & $\begin{array}{l}77,50 \pm 7,16 \\
79,00 \pm 9,66 \\
1,50\end{array}$ & 0,992 \\
\hline $\begin{array}{l}\text { RRSmax I } \\
\text { RRSmax II } \\
\Delta \\
{[\mathrm{mmHg}]}\end{array}$ & $\begin{array}{l}167,25 \pm 18,60 \\
172,00 \pm 18,45 \\
4,75\end{array}$ & 0,762 & $\begin{array}{l}152,50 \pm 19,15 \\
157,00 \pm 17,50 \\
4,50\end{array}$ & 0,800 & $\begin{array}{l}161,00 \pm 15,42 \\
171,50 \pm 20,00 \\
10,50\end{array}$ & 0,309 \\
\hline $\begin{array}{l}\text { RRDmax I } \\
\text { RRDmax II } \\
\Delta \\
{[\mathrm{mmHg}]}\end{array}$ & $\begin{array}{l}85,25 \pm 9,38 \\
83,50 \pm 9,33 \\
-1,75\end{array}$ & 0,954 & $\begin{array}{l}82,75 \pm 8,50 \\
81,00 \pm 7,18 \\
-1,75\end{array}$ & 0,954 & $\begin{array}{l}84,50 \pm 7,61 \\
85,00 \pm 11,05 \\
0,50\end{array}$ & 0,999 \\
\hline $\begin{array}{l}\text { DPrest I } \\
\text { DPrest II } \\
\Delta\end{array}$ & $\begin{array}{l}8355,50 \pm 1790,45 \\
8734,25 \pm 1418,03 \\
378,75\end{array}$ & 0,917 & $\begin{array}{l}9055,50 \pm 1785,57 \\
8798,00 \pm 1532,69 \\
-257,50\end{array}$ & 0,983 & $\begin{array}{l}10164,50 \pm 1530,31 \\
10626,00 \pm 1685,71 \\
461,50\end{array}$ & 0,954 \\
\hline $\begin{array}{l}\text { DPmax I } \\
\text { DPmax II } \\
\Delta\end{array}$ & $\begin{array}{l}20693,75 \pm 3563,36 \\
22577,25 \pm 3475,53 \\
1883,50\end{array}$ & 0,067 & $\begin{array}{l}19171,00 \pm 3909,31 \\
20643,00 \pm 2950,12 \\
1472,00\end{array}$ & 0,247 & $\begin{array}{l}21204,00 \pm 2601,58 \\
22779,00 \pm 3139,70 \\
1575,00\end{array}$ & 0,550 \\
\hline $\begin{array}{l}\mathrm{VO}_{2} \max \mathrm{I} \\
\mathrm{VO}_{2} \max \mathrm{II} \\
\Delta \\
{[\mathrm{ml} / \mathrm{kg} / \mathrm{min}]}\end{array}$ & $\begin{array}{l}38,43 \pm 6,24 \\
48,25 \pm 9,97 \\
9,82 \& \&\end{array}$ & 0,000 & $\begin{array}{l}38,42 \pm 4,34 \\
46,24 \pm 6,54 \\
7,81 \& \&\end{array}$ & 0,000 & $\begin{array}{l}39,75 \pm 5,55 \\
37,54 \pm 6,12 \\
-2,21\end{array}$ & 0,921 \\
\hline
\end{tabular}

Annotations: all data are presented as means \pm standard deviation and the difference $\left(\Delta-\right.$ delta). ${ }^{* *}-0,000$ IC vs $C,{ }^{* *}-0,003$ ST vs $\mathrm{C}, \# \#-0,007$ IC vs $\mathrm{C}$ and 0,004 ST vs $C, \& \&-0,001$ IC vs $C$ and 0,008 ST vs $C$.

Abbreviations: $p$ - level of statistical significance ( $p \leq 0,05$ for the lowest accepted), DPmax - maximum double product, DPrest - resting double product, HRmax maximum heart rate, HRrest - resting heart rate, MET — metabolic equivalent, RRDmax — maximum diastolic blood pressure, RRDrest - resting diastolic blood pressure, RRSmax - maximum systolic blood pressure, RRSrest - resting systolic blood pressure, $\mathrm{VO}_{2}$ max - maximal oxygen uptake, $\mathrm{n}$ - the number of patients.

ANOVA Kruskall-Wallis analysis was used. Assessing the relevance between arithmetic's the Tukey post hoc test was made. The obtained data was statistically analyzed by Statistica 12 (StatSoft), assuming a statistically significant result with a value of $\mathrm{p} \leq 0,05$.

\section{Results}

The Table 7 shows results of the treadmill exercise test in the three groups of patients before (I) and at the end (II) of cardiac rehabilitation. Compared to the initial result in the field of treadmill exercise test parameters in the IC group there was a significant increase in the test duration $(8,47$ vs $10,23 \mathrm{~min} ; \mathrm{p}<0,001)$, a significant increase in the MET value $(10,86$ vs 12,$35 ; \mathrm{p}=0,06)$ and $\mathrm{VO}_{2} \max (38,43$ vs $48,25 \mathrm{ml} / \mathrm{kg} / \mathrm{min} ; \mathrm{p}<0,001)$. Parallel changes were observed in the ST group, where the following parameters improved: the test duration $(8,51$ vs 9,$96 ; \mathrm{p}<0,001)$, MET value $(10,57$ vs 12,$18 ; \mathrm{p}=0,002)$ and the rate of $\mathrm{VO}_{2} \max$ 
Results of the blood lipid profile in three groups of patients before (I) and at the end (II) of cardiac rehabilitation

\begin{tabular}{|c|c|c|c|c|c|c|}
\hline Variable & $\begin{array}{l}\text { Indoor Cycling } \\
\text { group } \\
(n=20)\end{array}$ & $p$ & $\begin{array}{l}\text { Standard } \\
\text { group } \\
(n=20)\end{array}$ & $p$ & $\begin{array}{l}\text { Control } \\
\text { group } \\
(n=10)\end{array}$ & $p$ \\
\hline $\begin{array}{l}\mathrm{TCl} \\
\mathrm{TC} \text { II } \\
\Delta \\
{[\mathrm{mg} / \mathrm{dl}]}\end{array}$ & $\begin{array}{l}172,12 \pm 38,80 \\
160,60 \pm 30,13 \\
-11,51\end{array}$ & 0,339 & $\begin{array}{l}173,59 \pm 36,44 \\
158,77 \pm 26,95 \\
-14,82\end{array}$ & 0,113 & $\begin{array}{l}184,30 \pm 32,59 \\
177,70 \pm 13,65 \\
-6,60\end{array}$ & 0,961 \\
\hline $\begin{array}{l}\text { HDL I } \\
\text { HDL II } \\
\Delta \\
{[\mathrm{mg} / \mathrm{dl}]}\end{array}$ & $\begin{array}{l}46,35 \pm 13,11 \\
50,11 \pm 12,79 \\
3,75\end{array}$ & 0,312 & $\begin{array}{l}46,84 \pm 11,79 \\
49,09 \pm 13,81 \\
2,25\end{array}$ & 0,808 & $\begin{array}{l}41,00 \pm 12,29 \\
49,52 \pm 13,95 \\
8,52\end{array}$ & 0,018 \\
\hline $\begin{array}{l}\text { LDL I } \\
\text { LDL II } \\
\Delta \\
{[\mathrm{mg} / \mathrm{dl}]}\end{array}$ & $\begin{array}{l}108,05 \pm 29,91 \\
97,02 \pm 24,69 \\
-11,03\end{array}$ & 0,399 & $\begin{array}{l}97,17 \pm 31,79 \\
88,22 \pm 24,96 \\
-8,95\end{array}$ & 0,626 & $\begin{array}{l}126,60 \pm 22,59 \\
110,40 \pm 12,60 \\
-16,20\end{array}$ & 0,357 \\
\hline
\end{tabular}

Annotations: all data are presented as means \pm standard deviation and the difference $(\Delta-$ delta).

Abbreviations: $p$ - level statistically significant ( $p \leq 0,05$ for the lowest accepted), HDL - high density lipoprotein, $L D L-$ low density lipoprotein, TC - total cholesterol, $\mathrm{TG}$ - triglycerides, $\mathrm{n}$ - the number of patients.

$(38,42$ vs 46,$24 ; p<0,001)$. No significant changes in rest and maximum heart rate as well as systolic and diastolic blood pressure parameters were found. In $\mathrm{C}$ group no significant changes in treadmill exercise test parameters were observed.

The analysis also showed significant differences in $\Delta$ results between groups ( $\Delta$ of test duration between IC, S and $\mathrm{C}$ group, MET value as well as in $\mathrm{VO}_{2} \max$ ).

Table 8 presents the results of the blood lipid profile in three groups of patients before (I) and at the end (II) of cardiac rehabilitation. Alike in the IC, ST as well as in the $\mathrm{C}$ group, positive modifications of blood lipid profile - a reduction of total cholesterol level and triglycerides were observed. Preferable changes in the total cholesterol fractions - HDL and LDL were also noted. Besides the significant increase in the average value of HDL cholesterol in the control group (41,00 vs 49,52 mg/dl; $\mathrm{p}<0,05)$, another changes in the lipid profile of the groups were not statistically significant.

\section{Discussion}

Results presented in this study reveals the positive influence of application new, alternative strategy of the Indoor Cycling training on men with ischemic heart disease or after myocardial infarction. To our knowledge, this study shows for the first time in the literature the use of this type of physical activity in cardiology patients. Predominantly, in the literature attention is paid to improving exercise tolerance by the influence of standard forms of physical training in patients after myocardial infarction improvement of the treadmill test time and distance, increase in MET value [6].
Analysis of obtained results before and after the Indoor Cycling training shows its positive effect on physical capacity in patients. After training a significant increase in exercise capacity took place. In the final test in both groups of patients underwent cardiac rehabilitation parallel values of test duration, MET value and $\mathrm{VO}_{2}$ max were reported. Similarly, after 1-month of cardiac rehabilitation results were significantly improved in comparison with no rehabilitated group of patients. Maximum and resting heart rate, as well as maximum and resting systolic and diastolic blood pressure not changed significantly. No significantly changes of the treadmill exercise test were reported in control group.

In 2001 Belardinelli et al. analyzed the impact 6-month exercise training on functional parameters and quality of life of patients after PTCI or after applying stent. Patients were divided into two groups - practicing exercises (correspond to $2^{\text {nd }}$ stage of cardiac rehabilitation and included training on the ergometer three times a week) and those who prefer sedentary lifestyle, with the recommendation of irregular physical activity. The authors showed insignificant decrease in resting heart rate and a slight increase in peak heart rate in both groups. The mean systolic blood pressure were significantly $(\mathrm{p}<0,01)$ decreased in the training group (128 vs $122 \mathrm{mmHg}$ ), while in the group without the elements of regular physical activity systolic blood pressure significantly increased (125 vs $131 \mathrm{mmHg}$; $\mathrm{p}<0,01)$. In our analysis, in turn, showed no significant difference in resting and maximum systolic and diastolic blood pressure which can be associated with shorter period of our observation. Moreover, authors highlighted, that only trained patients had significant improvements in 
$\mathrm{VO}_{2 \text { peak }}(18,6$ vs $23,7 \mathrm{ml} / \mathrm{kg} / \mathrm{min} ; \mathrm{p}<0,001)$, which is consistent with our test results [7]. After the comprehensive cardiac rehabilitation sessions maximal oxygen uptake increased significantly only in participants, which confirms that only primarily programmed and systematic program of physical activity can contribute to positive changes in capacity. The same conclusion was reached in 2010 Korzeniowska-Kubacka et al. who analyzed the effect of 4,5-month exercise training on diastolic function of the left ventricle in 32 after myocardial infarction (16 men refused to participate - a control group) treated with percutaneous coronary intervention with preserved systolic function and mild diastolic dysfunction of the left ventricle. Authors observed a significant increase in the maximum consumption of oxygen in training group from 26,66 to $28,79 \mathrm{ml} / \mathrm{kg} / \mathrm{min} ; \mathrm{p}<0,0001$ and no significant change in this parameter in the control group $(26,23$ vs $26,34 \mathrm{ml} / \mathrm{kg} / \mathrm{min}$ ) [8].

In 2013 Paduch also noted the positive impact of 23-days cardiac rehabilitation (an A model of the $2^{\text {nd }}$ stage) on exercise capacity of patients after myocardial infarction. Author assessed, $\mathrm{VO}_{2}$ max which after rehabilitation program differ significantly from the result achieved prior to the initial test $(52,50$ vs 57,$48 ; \mathrm{p}<0,01)$. Correspondingly, author received a significant improvement in MET value $(8,57$ vs 8,$68 ; p<0,01)$. The author received a significant increase in maximal heart rate $(128,14$ vs 128,85 beats/minute; $p<0,05)$ and time of test duration $(670,42$ vs $707 \mathrm{~s} ; \mathrm{p}<0,001)$, as well as reduction of maximal diastolic blood pressure ( 88,57 vs. $85,71 \mathrm{mmHg}$; $\mathrm{p}<0,001)$. No significant changes in resting heart rate, resting systolic and diastolic, maximal systolic blood pressure were revealed [9].

In 2012 Ranković et al. investigated the effects of aerobic exercise training on cardiovascular parameters, lipid profile and endothelial function in seventy patients during second phase of cardiac rehabilitation with stable coronary artery disease. Authors divided patients into the two groups: the group I -33 patients with coronary artery disease and with regular aerobic training for 3 weeks in the center and 3 weeks after that in their home setting, and the group II (control) - 37 patients with ischaemic disease and sedentary lifestyle. Exercise training consisted of continual aerobic exercise for 45 minutes on a treadmill, bicycle ergometer or walking, three times a week. Authors noted that physical training induced significant reduction of systolic and diastolic blood pressure and heart rate after 6 weeks of cardiovascular rehabilitation $(\mathrm{p}<0,05)$. Such positive modifications were not registered in the control group. In patients with moderate aerobic physical training significantly lower heart rate was registered after a 6-week follow-up compared to the group with sedentary lifestyle $(\mathrm{p}<0,05)$. Authors highlighted that moderate aerobic physical training reduced systolic and diastolic blood pressure. In our observation we do not find significantly alterations in these parameters [10].
In 2009 Toufan and Afrasiabi evaluated effects of cardiac rehabilitation in 65 patients ( 50 males and 15 females) on functional capacity, maximum heart rate on exercise treadmill test and serum lipid profile. All of patients practiced aerobic training on bicycle or treadmill 30-40 minutes, 3 times a week for 8-12 weeks. After rehabilitation program $83 \%$ of patients improved their functional capacity - MET value increased from 8,7 to 10,$8 ; \mathrm{p}<0,001$. Also mean time of the tolerance exercise test improved from 7,76 to 9,56 minutes; $p<0,001$. Average left ventricular ejection fraction was $41 \%$ before program and in $72 \%$ of patients slightly improved. Alterations obtained by the authors are similar to ours. Maximal heart rate in $72 \%$ of patients decreased and in the rest of the population was unchanged or increased [11].

In our study the blood lipid profile was also analyzed. Before analysis, the total cholesterol, triglycerides, as well as the HDL fraction were normal in all of groups. Only in the control group the level of LDL cholesterol significantly different from the reference values.

The mechanism of regular physical activity of the LDL reduction, HDL cholesterol increased and lowering triglycerides most likely associated with an increased sensitivity to insulin, which enhances the expression of lipoprotein lipase in adipose tissue and skeletal muscle of physically active people [12]. Physical exercise may include a decrease in triglycerides and increase HDL level but little specific effect is seen in LDL cholesterol and total cholesterol (TC) [12]. The described changes in the blood lipid profile are important for the prevention and treatment of cardiovascular diseases, including coronary heart disease [13]. High HDL levels acts protectively [12] — an inverse relationship between HDL serum and the risk of coronary artery disease was demonstrated [14]. In this work, except for positive, significantly modification of the HDL fraction in control group, no noteworthy changes of the blood lipid profile were found.

Mentioned before Belardinelli et al. also made the blood lipid profile analysis of cardiac patients. In patients undergoing physical training value of total cholesterol significantly decreased from 235 to $212 \mathrm{mg} / \mathrm{dl}$, as well as the LDL cholesterol 148 vs $131 \mathrm{mg} / \mathrm{dl}$ (both changes in the level of $\mathrm{p}<0,001)$ and the value of TG (178 vs $155 \mathrm{mg} / \mathrm{dl}$; $\mathrm{p}=0,02)$. HDL cholesterol in turn increased but not significantly (34 vs $39,2 \mathrm{mg} / \mathrm{dl}$ ). In our study results were no significantly different after 1-month of patients practiced the Indoor Cycling training, which can be caused by to short time of observation (in opposite to 6-months of Balardinelli et al. However, among patients who did not practice regular physical activity after 6 months a significant increase in total cholesterol in blood serum (225 vs $255 \mathrm{mg} / \mathrm{dl} ; \mathrm{p}<0,001)$, LDL cholesterol (138 vs $148 \mathrm{mg} / \mathrm{dl}$; $\mathrm{p}<0,001)$ and TG (181 vs $189 \mathrm{mg} / \mathrm{dl}$ ) were noted. HDH fraction of cholesterol decreased from 32 to $28 \mathrm{mg} / \mathrm{dl}$. Significant changes between two groups occurred in the total cholesterol and LDL values $(\mathrm{p}<0,001)$ [8]. 
Quoted above Ranković et al. also investigated lipid profile and they noticed that effects of a 6-week cardiovascular rehabilitation on lipid parameters were visible in a significant reduction in triglycerides and significant increase in HDL cholesterol concentration $(p<0,05)$. The concentrations of triglycerides were significantly lower and HDL cholesterol significantly higher after in the exercise training group as compared to sedentary patients $(\mathrm{p}<0,05)$. Conclusions obtained by authors are different from our findings, which can caused by shorter follow-up time and lower population in our study [10].

Toufan and Afrasiabi in their study also received significant improvement in plasma lipid profile. Total cholesterol and LDL reduced in $75 \%$ of patients as well as triglycerides in 95\% of population during the rehabilitation program. Findings obtained by the authors are consistent with ours. [11].

In 2009 Damijan, in turn, analyzed the possibility of applying vibration training in cardiac rehabilitation. The author studied changes in total cholesterol level in blood serum and HDL cholesterol in 24 students, healthy subjects. The analysis showed that in $76 \%$ of population the total cholesterol significantly reduced from 4,53 to 4,30 $\mathrm{mmol} / 1(\mathrm{p}=0,044)$, and $76 \%$ of study population HDL cholesterol significantly increased from 1,26 to 1,33 $\mathrm{mmol} / \mathrm{l}(\mathrm{p}=0,038)$. According to the author insignificant decrease in patients' triglycerides ( 1,149 vs $0,980 \mathrm{mmol} / \mathrm{l})$ is valuable in terms of prevention of atherosclerosis as an independent risk factor [15].

\section{References}

1. Jerka K, Kurpesa M. Cardiac rehabilitation after myocardial infarction - current communications review. Pol Przeg Kardiol 2012; 14(2): 138-41.

2. Piotrowicz R, Wolszakiewicz J. Cardiac rehabilitation following myocardial infarction. Cardiol J 2008; 15(5): 481-7.

3. Niewiadomski P, Nowak Z, Cembrzyńska J, et a I. Współczesne formy treningu stosowane w II i III etapie rehabilitacji kardiologicznej. Rehabilitacja w Praktyce 2010; 3: 24-8.

Schmidt A. Indoor-Cycling. Meyer \& Meyer Verlag, Aachen 2008.

5. Foster C, Jackson AS, Pollock ML, et al. Generalized equations for predicting functional capacity from treadmill performance. Am Heart J 1984; 107: 1229-34.

6. Movahed H, Bao Cao L, Pitzalis M, et al. Beneficial effects of exercise training in patients with chronic heart failure. J Cardiol Therap 2013; 1(1): 20-33.

7. Belardinelli R, Paolini I, Cianci G, et al. Exercise training intervention after coronary angioplasty: The ETICA Trial. J Am Coll Cardiol 2001; 37(7): 1891-900.

8. Korzeniowska-Kubacka I, Bilińska M, Michalak, et al. Influence of exercise training on left ventricular diastolic function and its relationship to exercise capacity in patients after myocardial infarction. Cardiol J 2010; 17(2): 136-42.
Our study presents some limitations that are worth to be highlighted. For instance relatively small number of patients. Additionally, we investigated only men patients between 39-72 years which can be the most important factor of disturbing results. In fact, groups were similar to each other in characteristics. Finally, study lasted only 1-month, which is a short period of time to achieve stable changes in the physical performance and blood lipid profile of cardiology treated patients.

\section{Conclusion}

This study adds an important piece of evidence to the substantiation for exercise training in patients with coronary artery disease or after myocardial infarction. Study reports, that Indoor Cycling training can improve exercise capacity, have a favorable effect on blood lipid profile. Indoor Cycling training in the second phase of cardiac rehabilitation in patients with ischemic heart disease or after myocardial infarction is a safe form of therapy and therefore may be an interesting alternative method to the classic bicycle ergometer exercise in the stage of an early cardiac rehabilitation.

Acknowledgement. The results of the paper are part of $\mathrm{PhD}$ thesis of Dagmara Gloc. There were no grants, no external financial or technical support or other assistance during the evaluation of the paper. None of the authors declare conflict of interests.

9. Paduch P. The influence of outpatient cardiac rehabilitation on physical efficiency of patients subjected to myocardial infarction. Postępy rehabilitacji 2013; 3: 21-6.

10. Ranković G, Djindjić N, Ranković-Nedin G, et al. The effects of physical training on cardiovascular parameters, lipid disorders and endothelial function. Vojnosanit Pregl 2012; 69(11): 956-60.

11. Toufan M, Afrasiabi A. Benefits of cardiac rehabilitation on lipid profile in patients with coronary artery disease. Pak J Biol Sci 2009; 12(19): 1307-13.

12. Trejo-Gutierrez JF, Fletcher $\mathrm{G}$. Impact of exercise on blood lipids and lipoproteins. J Clin Lipidol 2007; 1(3): 175-81.

13. Mampuya WM. Cardiac rehabilitation past, present and future: an overview. Cardiovasc Diagn Ther 2012; 2(1): 38-49.

14. Bruckert E, Hansel B. HDL-c is a powerful lipid predictor of cardiovascular diseases. Int J Clin Pract 2007; 61(11): 1905-13.

15. Damijan Z. Vibration training in cardiologic rehabilitation. Acta Bio-Optica et Informatica Medica 2009; 4(15): 356-60 


\title{
NONLINEAR ANALYSIS OF HEART RATE DYNAMICS DURING RECOVERY FROM FLEXIBLE POLE EXERCISE INTERVENTION
}

\author{
Ana M.S. Antonio ${ }^{1}$, David M. Garner ${ }^{2}$, Rodrigo D. Raimundo ${ }^{3,4}$, Letícia S. de Oliveira ${ }^{1}$, Luiz Carlos de Abreu ${ }^{3,4}$, Marcelo T. Navega ${ }^{5}$, Vitor E.
} Valenti

Aim. Evaluated the acute effects of exercise with flexible pole on complex behavior of heart rate variability (HRV).

Material and methods. We investigated 32 healthy female volunteers aged between 18 and 25 years who executed a session of exercise with flexible pole. HRV was analyzed 10 minutes before and, 10 minutes' post-exercise. We then applied five entropic measures and Poincaré plot directly to the RR-intervals of the electrocardiographic signal.

Results. Sample entropy was significantly decreased during recovery from exercise with flexible pole $(0,8329 \pm 0,1111$ vs. $0,6568 \pm 0,1959 ; p<0,0001)$. The Poincaré plot indicated reduced dispersion of RR intervals after exercise, indicating reduced HRV. Conclusion. Exercise with flexible pole was able to acutely reduce chaotic behavior of heart rate dynamics measured by Sample Entropy alone. Care should be practiced when applying this exercise protocol to patients with cardiac diseases and/or abnormalities.

Russ J Cardiol 2016, 4 (132), Engl.: 160-164

http://dx.doi.org/10.15829/1560-4071-2016-4-eng-160-164

Key words: cardiovascular system, autonomic nervous system, cardiovascular physiological phenomena, rehabilitation, physical and rehabilitation medicine, exercise therapy.
${ }^{1}$ Centro de Estudos do Sistema Nervoso Autônomo (CESNA), Programa de PósGraduação em Fisioterapia, Faculdade de Ciências e Tecnologia, UNESP Presidente Prudente, SP, Brasil; ${ }^{2}$ Cardiorespiratory Research Group, Department of Biological and Medical Sciences, Faculty of Health and Life Sciences, Oxford Brookes University, Gipsy Lane, Oxford OX30BP, United Kingdom; ${ }^{3}$ Department of Environmental Health, Harvard School of Public Health, Boston, MA, United States of America; ${ }^{4}$ Laboratório de Delineamento em Pesquisas e Escrita Científica, Faculdade de Medicina do ABC, Santo André, SP, Brasil; ${ }^{5}$ Departamento de Fisioterapia e Terapia Ocupacional, Faculdade de Filosofia e Ciências, UNESP Marília, SP, Brasil.

Corresponding author. Vitor E. Valenti. Departamento de Fonoaudiologia, Av. Hygino Muzzi Filho, 737. 17.525-000 - Marília, SP, Phone: +55 (14) 3402-1300. E-mail: vitor.valenti@marilia.unesp.br

HRV - heart rate variability, ANS - autonomic nervous system.

\section{НЕЛИНЕЙНЫЙ АНАЛИЗ ДИНАМИКИ ЧАСТОТЫ СЕРДЕЧНЫХ СОКРАЩЕНИЙ ВО ВРЕМЯ ВОССТАНОВЛЕНИЯ ПОСЛЕ УПРАЖНЕНИЙ С ГИБКИМ ШЕСТОМ}

Ana M.S. Antonio ${ }^{1}$, David M. Garner ${ }^{2}$, Rodrigo D. Raimundo ${ }^{3,4}$, Letícia S. de Oliveira ${ }^{1}$, Luiz Carlos de Abreu ${ }^{3,4}$, Marcelo T. Navega ${ }^{5}$, Vitor E. Valenti

Цель. Оценить непосредственное действие упражнений с гибким шестом на сложное поведение вариабельности сердечного ритма (ВСР).

Материал и методы. Мы исследовали 32 здоровых женщин-добровольцев в возрасте от 18 до 25 лет, которые исполняли сеанс тренировки с гибким шестом. ВСР анализировали за 10 минут до и через 10 минут после тренировки. Затем мы применили пять измерений энтропии и гипотезу Пуанкаре напрямую к РР-интервалам ЭКГ сигнала.

Результаты. Энтропия образца была значительно снижена во время восстановления от физических упражнений с гибким шестом $( \pm 0,83290,1111$ и 0,6568 $\pm 0,1959 ; p<0,0001)$. Гипотеза Пуанкаре указывает на снижение дисперсии интервалов RR после тренировки, указывающих на снижение ВCP. Заключение. Упражнение с гибким шестом может уменьшить хаотическое поведение в динамике сердечного ритма и измеряется энтропией образца. Использование протокола тренировок для пациентов с заболеваниями сердца и/или иными отклонениями должно получить практическое применение.

Российский кардиологический журнал 2016, 4 (132), Англ.: 160-164 http://dx.doi.org/10.15829/1560-4071-2016-4-eng-160-164

Autonomic changes during recovery from exercise provides important information that may not be identified at rest [1]. The physiological response of the autonomic nervous system (ANS) to exercise is characterized by initial parasympathetic withdrawal and subsequent increase in sympathetic activity. Following exercise, the parasympathetic reactivation is involved in recovery of heart rate to the basal level [2, 3].
Ключевые слова: сердечно-сосудистая система, вегетативная нервная система, сердечно-сосудистые физиологические феномены, реабилитация, физическая и реабилитационная медицина, ЛФК.

${ }^{1}$ Centro de Estudos do Sistema Nervoso Autônomo (CESNA), Programa de PósGraduação em Fisioterapia, Faculdade de Ciências e Tecnologia, UNESP Presidente Prudente, SP, Бразилия; ${ }^{2}$ Cardiorespiratory Research Group, Department of Biological and Medical Sciences, Faculty of Health and Life Sciences, Oxford Brookes University, Gipsy Lane, Oxford OХ30ВP, Великобритания; ${ }^{3}$ Department of Environmental Health, Harvard School of Public Health, Boston, MA, United States of America; ${ }^{4}$ Laboratório de Delineamento em Pesquisas e Escrita Científica, Faculdade de Medicina do ABC, Santo André, SP, Бразилия; ${ }^{5}$ Departamento de Fisioterapia e Terapia Ocupacional, Faculdade de Filosofia e Ciências, UNESP Marília, SP, Бразилия.

Heart rate variability (HRV) is a simple, inexpensive, non-invasive and reliable measurement of heart rate autonomic regulation. Here we apply the algorithms directly to the RR-intervals derived from the PQRST-waveform of the signal [4].

Exercise with a flexible pole is a useful physiotherapy intervention for upper limb rehabilitation. Hitherto, its acute effects on cardiac autonomic regulation are unclear. 
A very recent study revealed that an acute session of flexible pole exercise induced significant changes in heart rate autonomic modulation [5], however, others found no significant change [6, 7]. Investigation of autonomic responses to exercise with flexible pole has relevant information for planning rehabilitation protocols in patients with cardiovascular disorders, since heart rate responses during recovery from exercise provides information regarding risk for cardiovascular events and sudden death [8].

In this sense, non-linear analysis of heart rate dynamics provides qualitative measurement of cardiovascular physiology and the susceptibility to "dynamical disease" [9] states while linear measurement of HRV is limited [4]. Previously, studies which applied geometric measures and linear indices [10] or chaotic global techniques [11] on HRV during recovery from exercise with flexible pole have so far proven inconclusive. Thus, we evaluated the acute effects of exercise with flexible pole on complex behavior of HRV through five entropic measures. These are enforced directly onto the RR-intervals with no power spectral step as is the case with chaotic global methods $[12,13]$. The techniques used here were Approximate [14], Sample [15], Shannon [16], Multiscale Renyi [17] and Multiscale Tsallis [18] entropies.

\section{Material and methods}

Study Population. To determine the sample size $a$ priori knowledge was required, based on Moreno et al. [19], a sample size of 18 participants was stipulated by a test of hypothesis (two-tail), with 5\% level of significance and $80 \%$ power.

This study consisted of 32 healthy female student subjects, all nonsmokers, aged 19,8 $\pm 1,6$ years old, height 1,62 $\pm 0,004$ $\mathrm{m}$, mass $58,8 \pm 10 \mathrm{~kg}$ and body mass index (BMI) of $22,2 \pm 3,7$ $\mathrm{kg} / \mathrm{m}^{2}$. All volunteers were informed about the procedures and objectives of the study and gave written informed consent. All study procedures were approved by the Ethics Committee in Research of the Faculty of Sciences of the UNESP, Campus of Marilia (No. 0554-2012), and were in accordance with Resolution 466/2012 National Health 10/10/1996.

Subjects under the following conditions were excluded: body mass index $(\mathrm{BMI})>35 \mathrm{~kg} / \mathrm{m}^{2}$; systolic blood pressure (SBP) $>140 \mathrm{mmHg}$ or diastolic blood pressure (DBP) $>90$ $\mathrm{mmHg}$ (at rest); reported cardiovascular, respiratory, endocrine and reported neurological disorders or any condition that did not allow the volunteers to perform the procedures. Subjects under medication that influence the ANS were not included. Volunteers were not evaluated on 10-15 days and 20-25 days after the first day of the menstrual cycle [20]. We also excluded physically active subjects according to the International Physical Activity Questionnaire (IPAQ) [21].

Initial Evaluation. Baseline information included: age, gender, mass, height and body mass index (BMI). Mass was determined using a digital scale (W 200/5, Welmy, Brazil) with a precision of $0,1 \mathrm{~kg}$. Height was established using a stadiometer (ES 2020, Sanny, Brazil) with a precision of 0,1 $\mathrm{cm}$ and with $220 \mathrm{~cm}$ of extension. BMI was calculated as

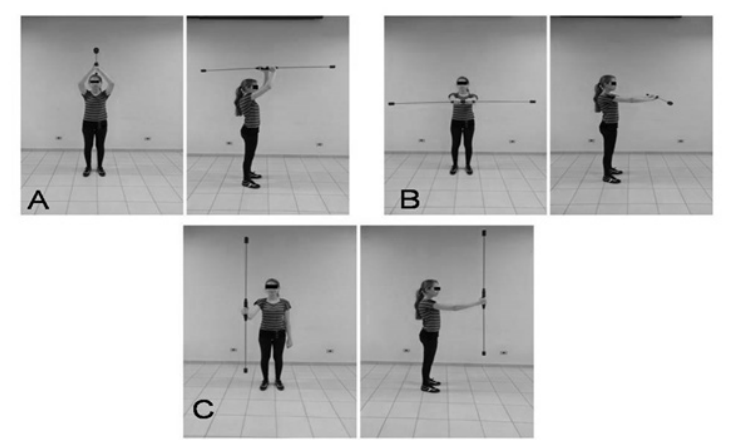

Figure 1. The exercise protocol was composed by the following exercise with both arms on three positions: I) with shoulders at approximately $180^{\circ}$ of flexion with the flexible pole on the frontal plane, parallel to the ground (Figure $1 \mathrm{~A}), \mathrm{I}$ ) with the shoulders on $90^{\circ}$ of flexion with the flexible pole on the transverse plane (Figure $1 \mathrm{~B}$ ), and III) one shoulder at $90^{\circ}$ of flexion with the flexible pole on the sagittal plane, perpendicular to the ground (Figure $1 \mathrm{C}$ ).

mass / height ${ }^{2}$, with mass in kilograms and height in metres.

Exercise with flexible pole. The flexible pole is an apparatus with a mass of $0,8 \mathrm{~kg}$ and of approximately $150 \mathrm{~cm}$ length. The flexible pole provides oscillations induced by movements of the upper limbs. Exercise protocols using the flexible pole have been proven to present positive results in shoulder muscle function training [22].

The flexible pole exercises were undertaken (Figure 1) with volunteers at standing position with feet apart (wide base) and shoulder flexion as the proposed position. To maintain the proper shoulder flexion in each upper limb it was used as a target visual feedback with a metronome to oscillate the pole $(5 \mathrm{~Hz})$. All exercises were performed for 15 seconds with 50 to 60 seconds of rest between each exercise. Three repetitions were performed for each exercise [11].

HRV analysis. We enforced procedure from Task Force guidelines [23]. Instantaneous RR intervals (RRi) were recorded with a digital telemetry system (Polar ${ }^{\circledR}$ RS800CX; Polar Electro Oy, Kempele, Finland). This system detected ventricular depolarization, corresponding to the $\mathrm{R}$ wave on the electrocardiogram, at a sampling rate of $1000 \mathrm{~Hz}$, providing a temporal resolution of 1 millisecond for each RR interval and was previously validated [24]. The Polar heart rate device consisted of' an elastic band and two electrodes worn by the volunteer around the chest, at the level of the xiphoid process just below the pectoralis muscles according to the manufacturer guidelines. To ensure proper signal detection, water was placed on the front two electrodes of the chest strap. RR intervals were then downloaded to the Polar Precision Performance program (v. 3.0, Polar Electro, Finland). The software enabled the visualization of HR and the extraction of a cardiac period (RR interval) file in "txt" format. Following digital filtering complemented with manual filtering for the elimination of artefacts, which were replaced by linear interpolation of adjacent beats, 500 (short-term) stable RR intervals were applied for the data analysis. Only series with more than $95 \%$ sinus rhythm were included in the study [23, 25]. 

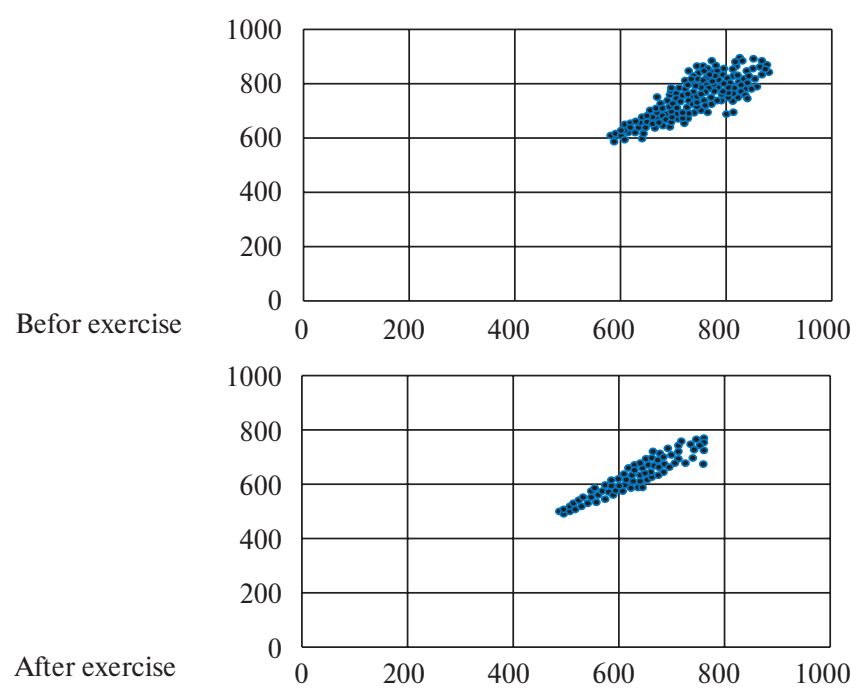

Figure 2. Visual pattern of Poincaré plot observed in one subject before exercise and after exercise.

HRV was analysed in the following periods: control protocol - the 10-minute period before the performance of the exercises and the 10-minute period after the performance with flexible pole - the recovery phase.

Protocol. Data collection was undertaken in the same soundproofed room for all volunteers. The temperature was between $21^{\circ} \mathrm{C}$ and $25^{\circ} \mathrm{C}$ and, the relative humidity was between $50 \%$ and $60 \%$. Volunteers were instructed not to consume alcohol, caffeine or other ANS stimulants for 24 hours before the evaluation. Data was collected on an individual basis, always between 18:00 and 21:00 to standardize circadian influences. All procedures necessary for the data collection were explained to each subject separately, and the subjects were instructed to remain at rest and avoid talking during the collection.

Poincaré plot. The plot was qualitatively analysed by HRV analysis software based on the figures formed by its attractor. The expected shapes were described by Tulppo et al [26] as:

1) Figures in which an increase in the dispersion of RR intervals is observed with increased intervals, characteristic of a normal plot.

2) Small figures with beat-to-beat global dispersion without increased long-term dispersion of RR intervals.

Shannon Entropy. Entropy is a benchmark of the disorder in dynamical systems, a statistical complexity measurement derived from information theory. Generally, entropy as a measure of lack of knowledge is useful in many situations. For conditions where the connection with physical temperature is unimportant, the Boltzmann's constant can be removed. This normalisation gives us the Shannon entropy [27].

Entropy-based techniques are routinely employed in analysis of medical data especially cardiovascular [29, 30], respiratory [31, 32] and neurological signals [33, 34]. A low entropy dataset is highly predictable - whereas a high entropy dataset is less predictable. Accordingly, high entropy is more disordered. All entropies are numerically expressed between zero and unity with zero being the lowest disorder.

In contrast to Tsallis and Rényi entropies (see below); Shannon entropy is additive. Consequently, if the probabilities can be factorised into independent factors, the entropy of the joint process is the sum of the entropies of the separate processes.

Multiscale Rényi Entropy. The order-q Rényi entropies are a series of entropy like quantities. Here we set the value, entropic order, $\alpha$ to $0.25,0.35,0.45,0.55,0.65$, 0.75 . Where $\alpha=1$ the function is the Shannon entropy and when $\alpha=2$ it is the squared entropy. When $\alpha$ is varied this provides the multi-scale measure; $\alpha=0$ is simply the logarithm of $n$. As $\alpha$ is increasing the measures become more sensitive to the values occurring at a higher probability and less to those at a lower probability.

Multiscale Tsallis Entropy. Tsallis entropy is a generalization of the standard Shannon-Boltzmann-Gibbs entropy. It was introduced as a basis for generalizing the standard statistical mechanics. Here we set entropic index, $q$ to $0.25,0.35,0.45,0.55,0.65,0.75$. Where $q=1$ it is the Shannon-Boltzmann-Gibbs entropy.

Approximate Entropy. Approximate entropy is the logarithmic ratio of component wise matching sequences from the signal length, $N$. Other relevant parameters involve $r$ which we set to 0.2 of the standard deviation based on factors of the signal that is being analysed and compared to. The factor $m$, is the length of sequences compared which we set to window of 2 . It is measured as an integer count of discrete time bins. A minimum value of zero for Approximate entropy would indicate a fully predictable series. Approximate entropy is described algorithmically in Hornero et al [35].

Sample Entropy. It is important to consider Approximate entropy and Sample entropy together as similar mathematical functions. Comparisions with fixed $m, r$, and $N . N$ is the length of the time series and $m$ is the length of the sequences to be compared whereas $r$ is the tolerance for accepting matches. As with Approximate entropy in this study we set $r$ to 0.2 of the standard deviation. The factor $m$, is the length of sequences compared which we set to window of 2. Again the algorithm for Sample entropy is discussed in Hornero et al [35].

\section{Results}

The visual analysis through the Poincaré plot illustrated that RR intervals dispersion reduced immediately after exercise with flexible pole (Figure 2).

Normalization of the data is required to decide the necessary statistical test of significance to apply. Here, we applied the Anderson-Darling [36] and Lilliefors tests [37]. The Anderson-Darling test for normality applies an empirical cumulative distribution function. The Lilliefors test is suitable when the number of subjects is low. Here, there are only 32 subjects in each cohort. The results from both tests 
Mean values, standard deviation and $p$-value of significance for the five entropic measures

\begin{tabular}{|c|c|c|c|c|}
\hline \multirow[t]{2}{*}{ Entropic Parameter } & Mean \pm SD & Mean \pm SD & ANOVA1 & Kruskal-Wallis \\
\hline & Pre $(n=32)$ & Recovery $(n=32)$ & (p-value) & (p-value) \\
\hline Approximate & $0,9091 \pm 0,0779$ & $0,8346 \pm 0,2294$ & 0,0871 & 0,2243 \\
\hline Sample & $0,8329 \pm 0,1111$ & $0,6568 \pm 0,1959$ & $<0,0001^{\star}$ & $<0,0001^{*}$ \\
\hline Shannon & $0,7612 \pm 0,1089$ & $0,7286 \pm 0,1200$ & 0,2595 & 0,1379 \\
\hline Rényi $\alpha=0,25$ & $0,9922 \pm 0,0039$ & $0,9910 \pm 0,0043$ & 0,2215 & 0,1452 \\
\hline$\alpha=0,35$ & $0,9900 \pm 0,0050$ & $0,9884 \pm 0,0056$ & 0,2209 & 0,1415 \\
\hline$\alpha=0,45$ & $0,9881 \pm 0,0059$ & $0,9861 \pm 0,0067$ & 0,2204 & 0,1415 \\
\hline$\alpha=0,55$ & $0,9864 \pm 0,0068$ & $0,9842 \pm 0,0075$ & 0,2199 & 0,1415 \\
\hline$\alpha=0,65$ & $0,9850 \pm 0,0075$ & $0,9825 \pm 0,0084$ & 0,2195 & 0,1415 \\
\hline$\alpha=0,75$ & $0,9837 \pm 0,0081$ & $0,9810 \pm 0,0091$ & 0,2190 & 0,1379 \\
\hline Tsallis $q=0,25$ & $0,7870 \pm 0,0980$ & $0,7574 \pm 0,1082$ & 0,2551 & 0,1379 \\
\hline$q=0,35$ & $0,7864 \pm 0,0983$ & $0,7567 \pm 0,1085$ & 0,2551 & 0,1379 \\
\hline$q=0,45$ & $0,7853 \pm 0,0987$ & $0,7555 \pm 0,1090$ & 0,2552 & 0,1379 \\
\hline$q=0,55$ & $0,7836 \pm 0,0995$ & $0,7536 \pm 0,1098$ & 0,2553 & 0,1379 \\
\hline$q=0,75$ & $0,7774 \pm 0,1021$ & $0,7466 \pm 0,1127$ & 0,2563 & 0,1379 \\
\hline
\end{tabular}

Annotation: the table below shows the mean values, standard deviation and p-value of significance for the five entropic measures for normal subjects and subjects recovering from flexible pole exercises related to RR-intervals. The number of RR-intervals was 500; and after tests of normality ANOVA1 and Kruskal-Wallis tests of significance were applied. For Multiscale Rényi and Multiscale Tsallis entropy the values we calculated were for six values of entropic order and entropic index. For Approximate entropy and Sample entropy ( $m=2$ and $r=0,2)$. Both statistical tests are significant for Sample Entropy at $(p<0,0001)$; where * is highly significant.

were inconclusive. Accordingly, both the parametric oneway analysis of variance; (ANOVA1) and the non-parametric Kruskal-Wallis [38] tests of significance must be applied. Dissimilarities would be considered weakly significant when the probability of a type I error was less than $5 \%(\mathrm{p}<0,05)$. Further significance is achieved at the level of the probability of a type I error was less than $1 \%(\mathrm{p}<0.01)$ (Table 1).

\section{Discussion}

For cardiovascular and, HRV responses in particular, flexible pole exercise performance has been explored previously in the time and frequency domain indices [10, 11]. Traditional linear analysis of HRV did not find statistically significant responses induced by flexible pole exercise in women, suggesting well-being and safety when performing this exercise [7, 10].

Here, we investigated HRV through entropic analysis and reported the presence of levels chaotic behavior of HRV before and immediately after a 10 minute session of exercise with the flexible pole. Statistical significance was achieved with the Sample entropy algorithm. Since there is only one significant parameter the multivariate techniques [39] applied in similar studies [40] is not required. In this context, our findings do not support the cardiac autonomic safety of flexible pole exercise as previously recommended based on linear HRV indices [8, 10].

This measurement is useful for assessments of the intensity of physiotherapy and rehabilitative treatment required in such patients; and their future susceptibility to cardiovascular irregularities and "dynamical diseases" when undergoing the protocol.

Sample entropy presented in our study is proposed to quantify the entropy rate of short- to mid-length RR inter- vals, it indicates the complexity of HRV. Small values of Sample entropy are associated to more regular, predictable, processes. Conversely, the greater the complexity, the more physiologically adapted the organism [41].

According to our results, the Sample entropy has decreased when recovering from flexible pole exercises, indicating reduced chaotic behavior during this phase.

This technique which can assess the level of chaotic response to exercise is useful in determining the intensity of the physiotherapy intervention and the risk from cardiovascular pathology and "dynamical diseases" generally in subjects undergoing the protocol.

Contrariwise, Shannon, Multiscale Rényi, Multiscales Tsallis and Approximate entropies measurements were not significantly changed by flexible pole exercise.

Previous investigations also examined HRV responses to the same exercise protocol with flexible pole. De Oliveira et al [7], investigated HRV 30 minutes after exercise with flexible pole. Time and frequency domain and geometric indices of HRV were not significantly changed compared to control rest before exercise.

Dos Santos et al [6], failed to find significant responses of time and frequency domain indices of HRV in women submitted to a single session of exercise with flexible pole. The authors analyzed the initial 60 minutes during recovery from exercise.

However, Ogata et al [5], reported significant heart rate dynamics change induced by flexible pole exercise in healthy men. A decline was reported in parasympathetic heart rate modulation immediately after the exercise protocol, which continued for the initial 10-15 minutes during recovery from exercise.

We may postulate that the difference between studies in men [5] and women [6, 7] is due to increased muscle mass 
in men, which may be involved in more intense mechanoreflex responses.

Our data suggests a diminished complex response of heart rate dynamics followed flexible pole exercise, which were not previously detected by linear indices of $\operatorname{HRV}[6,7$, 10]. In this way, nonlinear HRV evaluated through global chaotic analysis displayed reduction in chaotic behavior immediately after exercise with flexible pole [11], which reinforces our outcomes. Further studies are necessary to investigate the chronic effects of this exercise protocol.

Application of flexible pole exercises has been extensively applied in rehabilitation and physiotherapy clinics. Despite that, there are few scientific studies supporting its effectiveness. Knowledge of the feasibility of its use can provide greater safety in patients with neurological, cardiac and metabolic disorders undergoing the treatment.

\section{References}

1. Peçanha T, Silva-Júnior ND, Forjaz CL. Heart rate recovery: autonomic determinants, methods of assessment and association with mortality and cardiovascular diseases. Clin Physiol Funct Imaging. 2014 Sep;34(5):327-39.

2. Pescatello LS, Guidry MA, Blanchard BE, et al. Exercise intensity alters postexercise hypotension. Journal of hypertension. 2004;22(10):1881-8

3. Moreno IL, Pastre CM, Ferreira C, et al. Effects of an isotonic beverage on autonomic regulation during and after exercise. Journal of the International Society of Sports Nutrition. 2013;10(1):2

4. Valenti VE. Heart rate variability as a functional marker of development. Journal of Human Growth and Development. 2015; 25:137-140.

5. Ogata CM, Navega MT, Abreu LC, et al. A single bout of exercise with a flexible pole induces significant cardiac autonomic responses in healthy men. Clinics (Sao Paulo). 2014 Sep;69(9):595-600.

6. Dos Santos António AM, Navega MT, Cardoso MA, et al. Cardiac autonomic responses induced by a single bout of exercise with flexible pole. Int Arch Med. 2014 Sep 23;7(1):40.

7. de Oliveira LS, Moreira PS, Antonio AM, et al. Acute effects of flexible pole exercise on heart rate dynamics. Rev Port Cardiol. 2015 Jan;34(1):35-42.

8. Jouven X, Empana J-P, Schwartz PJ, et al. Heart-Rate Profile during Exercise as a Predictor of Sudden Death. N Engl J Med. 2005;352:1951-8.

9. Mackey MC, Milton JG. Dynamical diseases. Annals of the New York Academy of Sciences. 1987;504(1):16-32

10. Morini SM, dos Santos CA, Antonio AMS, et al. Geometric and linear indices of heart rate variability during an exercise with flexible pole. Russ J Cardiol. 2015;4(120):13-9.

11. Antonio AMS, Garner DM, Cardoso MA, et al. Behaviour of globally chaotic parameters of heart rate variability following a protocol of exercise with flexible pole. Russ $\mathrm{J}$ Cardiol. 2015:4(120):24-8

12. Garner DM, Ling BWK. Measuring and locating zones of chaos and irregularity. J Syst Sci Complex. 2014;27(3):494-506

13. Wajnsztejn R, De Carvalho TD, Garner DM, et al. Heart rate variability analysis by chaotic global techniques in children with attention deficit hyperactivity disorder. Complexity. 2015.

14. Pincus SM. Approximate entropy as a measure of system complexity. Proceedings of the National Academy of Sciences. 1991;88(6):2297-301.

15. Richman JS, Moorman JR. Physiological time-series analysis using approximate entropy and sample entropy. American journal of physiology Heart and circulatory physiology. 2000;278(6):H2039-49.

16. Shannon CE. A Mathematical Theory of Communication. The Bell System Technical Journal. 1948;27:379-423.

17. Zyczkowski K. Renyi extrapolation of Shannon entropy. Open Systems \& Information Dynamics. 2003;3(10):297-310

18. dos Santos RJ. Generalization of Shannon's theorem for Tsallis entropy. Journal of Mathematical Physics. 1997;38(8):4104.

19. Moreno IL, Pastre CM, Ferreira C, Effects of an isotonic beverage on autonomic regulation during and after exercise. J Int Soc Sports Nutr. 2013 Jan 4;10(1):2.

20. Bai X, Li J, Zhou L, Li X. Influence of the menstrual cycle on nonlinear properties of heart rate variability in young women. American Journal of Physiology-Heart and Circulatory Physiology. 2009;297(2):H765-H74.

21. Rzewnicki R, Auweele W, Bourdeaudhuij ID. Addressing overreporting on the International Physical Activity Questionnaire (IPAQ) telephone survey with a population sample. Public Health Nutrition. 2003;6(03):299-305.
The application of the protocol in young adults and the lack of research in this area could be a opinion addressed in this study. However, we evaluated only females in order to avoid gender related effects.

\section{Conclusion}

An acute session of exercise with a flexible pole reduced the chaotic behavior of heart rate dynamics assessed through the technique Sample Entropy. We suggest that clinicians take care when using this treatment protocol in patients presenting with cardiovascular disorders.

Acknowledgements. The authors declare that there is no conflict of interests regarding the publication of this article. The study received financial support from FAPESP (number 2012/09043-1).

22. Sugimoto $D$, Blanpied $P$. Flexible foil exercise and shoulder internal and external rotation strength. Journal of athletic training. 2006;41(3):280.

23. Camm AJ, Malik M, Bigger JT, et al. Heart rate variability: standards of measurement, physiological interpretation and clinical use. Task Force of the European Society of Cardiology and the North American Society of Pacing and Electrophysiology. Circulation 1996:93:1043-1065.

24. Barbosa MPR, Silva NT, Azevedo FM, et al.Comparison of Polar ${ }^{\circledR}$ RS800G $3^{\text {TM }}$ heart rate monitor with Polar ${ }^{\circledR} \mathrm{S} 810 \mathrm{i}^{\mathrm{TM}}$ and electrocardiogram to obtain the series of RR intervals and analysis of heart rate variability at rest. Clin Physiol Funct Imaging 2014. In press.

25. Vanderlei LCM, Pastre CM, Hoshi RA, et al. Basic notions of heart rate variability and its clinical applicability. Revista Brazileira de Cirurgia Cardiovascular. 2009;24(2):205-17.

26. Tulppo MP, Mäkikallio TH, Seppänen $T$, et al. Vagal modulation of heart rate during exercise: effects of age and physical fitness. Am J Physiol 1998;274:H424-H429.

27. Shannon CE. A mathematical theory of communication. ACM SIGMOBILE Mobile Computing and Communications Review. 2001;5(1):3-55

28. Bernardo AFB, Vanderlei LCM, Garner DM. HRV Analysis - A clinical and diagnostic tool in Chronic Obstructive Pulmonary Disease. International Scholarly Research Notices. 2014;2014:1-6.

29. Fontes AM, Garner DM, De Abreu LC, et al. Global chaotic parameters of heart rate variability during mental task. Complexity. 2015;4(120).

30. Gomes Fontes AM, Guida HL, Barbosa JC, et al. Auditory stimulation with music intensifies cardiac autonomic responses to a mental task. Focus on Alternative and Complementary Therapies. 2014;19(4):198-207.

31. Walsh TS, Ramsay P, Lapinlampi TP, et al. An assessment of the validity of spectral entropy as a measure of sedation state in mechanically ventilated critically ill patients. Intensive Care Med. 2008;34(2):308-15.

32. Wysocki M, Fiamma MN, Straus C, et al.Chaotic dynamics of resting ventilatory flow in humans assessed through noise titration. Respiratory physiology \& neurobiology. 2006;153(1):54-65

33. Ponnusamy A, Marques $\mathrm{JL}$, Reuber M. Comparison of heart rate variability parameters during complex partial seizures and psychogenic nonepileptic seizures. Epilepsia. 2012;53(8):1314-21

34. Abasolo D, Hornero R, Espino P, et al. Entropy analysis of the EEG background activity in Alzheimer's disease patients. Physiol Meas. 2006;27(3):241-53.

35. Hornero R, Abasolo D, Escudero J, Gomez C. Nonlinear analysis of electroencephalogram and magnetoencephalogram recordings in patients with Alzheimer's disease. Philosophical transactions Series A, Mathematical, physical, and engineering sciences 2009;367(1887):317-36

36. Anderson TW, Darling DA. A test of goodness of fit. Journal of the American Statistical Association. 1954:49(268):765-9.

37. Razali NM, Wah YB. Power comparisons of shapiro-wilk, kolmogorov-smirnov, lilliefors and anderson-darling tests. Journal of Statistical Modeling and Analytics. 2011;2(1):21-33

38. Kruskal WH, Wallis WA. Use of ranks in one-criterion variance analysis. Journal of theAmerican Statistical Association. 1952;260(47):583-621.

39. Jolliffe I. Principal component analysis: Wiley Online Library; 2005

40. Vanderlei F, Vanderlei LCM, de Abreu LC, Garner D. Entropic Analysis of HRV in Obese Children. International Archives of Medicine. 2015;8.

41. Sassi R, Cerutti S, Lombardi F, et al. Advances in heart rate variability signal analysis: joint position statement by the e-Cardiology ESC Working Group and the European Heart Rhythm Association co-endorsed by the Asia Pacific Heart Rhythm Society. Europace. 2015 Sep;17(9):1341-53. 